\title{
Jejaring Kemitraan Dalam Pemahaman Pengelola Lembaga Pendidikan Non-Formal
}

\author{
Suryawahyuni Latief ${ }^{1}$, Santi Hendrayani ${ }^{2}$, Samsuddin $^{3}$ \\ ${ }^{1}$ Universitas Nurdin Hamzah Jambi, Indonesia \\ e-mail: niniek_yuni@yahoo.com \\ ${ }^{2}$ Universitas Nurdin Hamzah Jambi, Indonesia \\ e-mail: santihendrayani@gmail.com \\ ${ }^{3}$ Universitas Nurdin Hamzah Jambi, Indonesia \\ e-mail: samsudinmip@gmail.com
}

\begin{abstract}
PKBM as non-formal education provider in the form of equality education and life skills cannot stand alone to carry out its duties and roles. Therefore PKBM builds partnership networks with other parties so that roles and functions can be achieved, given the limited resources owned by PKBM units. The purpose of this study is to describe how the understanding of PKBM unit managers in building partnership networks. To answer the research objectives in general, the researcher explores information regarding the meaning of partnership networks for PKBM unit managers, characteristics of partnership networks, and factors that become obstacles in building partnership networks.

This study uses a qualitative descriptive research method, involving 15 PKBM unit managers from several districts in Jambi Province, namely Batanghari, Merangin and Muaro Bungo. Data collected through observation, interviews, and documents were analyzed by following the steps of data analysis in qualitative research. The data that has been analyzed is tested for its validity in theory, field sources, and other sources.

This study found that the understanding of building a partnership network for PKBM unit managers was limited to a practical understanding so that the available service programs could run according to plan with the limited resources of the PKBM unit. Therefore, this needs to be addressed by providing direct experience to PKBM unit managers through visits to other PKBM units that serve as references and providing training regarding PKBM management. The results of this study can be used for the development of community-based educational organizations.
\end{abstract}

Keywords: partnership network, PKBM, manager understanding

\section{Pendahuluan}

Salah satu aspek penting dalam kehidupan suatu bangsa adalah pendidikan, karena melalui pendidikan peradaban semakin maju dan kesejahteraan semakin meningkat. Penyelenggaraan pendidikan dalam suatu negara dilakukan melalui tiga jalur yaitu formal, non-formal, dan informal. Ketiga jalur pendidikan tersebut memiliki ciri tersendiri dalam penyelenggaraannya. Pendidikan non-formal berdasarkan undang-undang sistem pendidikan nasional tahun 2003 pasal 1 ayat 11 menyebutkan bahwa pendidikan 
non formal adalah jalur pendidikan yang dapat dilaksanakan secara terstruktur dan berjenjang.

Terkait penyelenggaraan pendidikan non-formal, undang-undang sistem pendidikan nasional nomor 20 tahun 2003 pasal 26 menjelaskan pendidikan non-formal sebagai salah satu organisasi pendidikan yang diselenggarakan oleh masyarakat dan berfungsi sebagai pengganti, penambah, dan /atau pelengkap pendidikan formal dalam rangka mendukung pendidikan sepanjang hayat, meliputi pendidikan kecakapan hidup, pendidikan anak usia dini, pendidikan, kepemudaan, pendidikan pemverdayaan perempuan, pendidikan keaksaraan, pendidikan keterampilan dan pelatihan kerja, pendidikan kesetaraan, serta pendidikan lain yang ditujukan untuk mengembangkan kemampuan peserta didik serta terdiri atas lembaga kursus, lembaga pelatihan, kelompok belajar, pusat kegiatan belajar masyarakat, majelis taklim dan satuan pendidikan yang sejenis. Selanjutnya pendidikan non-formal berdasarkan peraturan pemerintah nomor 81 pasal 2 tahun 2013 dapat didirikan oleh orang/perseorangan, kelompok orang dan/atau badan hukum.

Sebagai organisasi pendidikan yang diselenggarakan oleh masyarakat dan memiliki peran penting, maka dalam penyelenggaraan pendidikan nonformal diperlukan jaringan kemitraan dengan organisasi lain untuk menghadapi persaingan dan perubahan lingkungan yang menuntut peran nyata pendidikan nonformal sebagai penyelenggara pendidikan nonformal untuk mewujudkan tujuan penyelenggaraan pendidikan non-formal secara umum dan tujuan satuan secara khusus karena terbatasnya sumberdaya yang dimiliki oleh satuan pendidikan nonformal dan sumberdaya lain yang penting berada pada organisasi lainnya.

Hal ini, menjadikan satuan pendidikan nonformal berusaha untuk mendapatkan dukungan sumberdaya yang tidak dimiliki oleh satuannya agar dapat mewujudkan tujuan umum dan tujuan khusus penyelenggaraan pendidikan di satuannya melalui kerjasama dengan organisasi atau pihak lain. Oleh karena itu satuan pendidikan non-formal perlu melakukan jaringan kemitraan antar pihak atau organisasi lain agar tujuan penyelenggaraan dapat tercapai.

Keberadaan pendidikan nonformal dilandasi pada kenyatan bahwa pendidikan formal belum sepenuhnya memberikan ketersedian kesempatan pendidikan formal, dimana masih banyak ditemui warga negara yang belum menyelsaikan pendidikan pada pendidikan dasar menengah dikarenakan berbagai faktor baik yang bersumber dari diri 
sendiri maupun dari luar seperti kemiskinan dan jarak tempuh pendidikan formal yang sangat jauh dari pemukiman masyarakat.

Menurut Coombs dalam Joesoef (1992) pendidikan nonformal memiliki pengertian sebagai kegiatan pendidikan yang diselenggarakan secara terorganisir diluar sistem pendidikan formal yang bertujuan untuk memberikan layanan kepada sasaran didik tertentu sebagai upaya pencapaian tujuan belajar. Pendidikan nonformal merupakan situasi terjadinya komunikasi yang teratur dan terarah di luar sekolah untuk memperoleh informasi, pngetahuan dan latihan sesuai dengan usia dan kebutuhan hidupnya yang bertujuan untuk mengembangkan tingkat keterampilan, sikap, nilai yang menyebabkan diri individu bermanfaat bagi lingkungannya (Marzuki, 2009)

Penyelenggaraan pendidikan non-formal memiliki peran penting dalam menyediakan pendidikan di luar sekolah (Rahma-Arina, Zulkarnain, Desyanti-Sugeng, \& Wahyuni, 2019; Ariefianto, 2020; Rahayu, 2020). Suryono dan Tohani (2016) mengemukakan bahwa pendidikan nonformal berperan dalam mengurangi angka putus sekolah, angka tidak melanjutkan ke jenjang pendidikan selanjutnya, mengurangi angka pengangguran, dan menyiapkan tenaga kerja sektor informal. Suryono dan Tohani (2017) menjelaskan pendidikan nonformal berperan dalam mengurangi angka putus sekolah, angka tidak melanjutkan pendidikan ke jenjangan selanjutnya, dan angka pengangguran untuk mempersiapkan tenaga kerja untuk sektor informal.

Menurut Kedyarate (2012) pendidikan nonformal dilaksanakan untuk menyediakan nilai, pengetahuan, dan keterampilan dengan biaya yang terjangkau. Sedangkan fungsi satuan pendidikan nonformal menurut Folley (2000) adalah sebagai berikut:

1. Meningkatkan kemampuan kognitif individu melalui pengetahuan yang bermakna;

2. Pengembangan kualitas dan pengaktualisasian diri individu;

3. Meningkatkann pertumbuhan individu dan memelihara masyarakat demokratis yang sehat;

4. Mempertahankan tatanan sosial yaitu pendidikan sebagai sarana transformasi sosial;

5. Upaya pengembangan sikap dan keterampilan yang dibutuhkan.

Fungsi pendidikan nonformal menurut Rahmat (2017: 8) adalah:

1. Melayani peserta didik agar dapat tumbuh dan berkembang sejak dini dan sepanjang hayat demi meningkatkan martabat dan mutu kehidupannya; 
2. Memberikan pengetahuan, keterampilandan sikap mental yang diperlukan bagi peserta didik untuk mengembangkan diri, bekerjaa mencari nafkah atau melanjutkan dan /atau jenjang yang lebih tinggi;

3. Memenuhi kebutuhan belajar masyarakat yang tidak dapat dipenuhi dalam jalur pendidikan sekolah.

Sedangkan UNESCO dalam Rahmat (2017) menyatakan bahwa tujuan pendidikan nonformal adalah:

1. Untuk memberikan latihan dan ilmu sehingga manusia memiliki kepribadian yang bermartabat;

2. Menjadikan individu lebih kreatif, bersikap kritis, dan menyuburkan kreativitas;

3. Mempersiapkan individu yang mampu berinteraksi dan memiliki tanggungjawab;

4. Mengembangkan potensi individu semaksimal mungkin dalam batas kemampuannya.

Maka dapat disimpulkan bahwa pendidikan nonformal adalah penyelenggaraan aktivitas belajar dan mengajar yang berada diluar sekolah, dilakukan oleh masyarakat sebagai bentuk pemenuhan pendidikan bagi masyarakat yang memiliki alasan tertentu sehingga tidak dapat menempuh jalur pendidikan formal dan mengutamakan pendidikan dasar dan menengah serta keterampilan hidup. Selanjutnya, pendidikan nonformal yang diselenggarakan oleh masyarakat bertujuan untuk memenuhi kebutuhan dasar individu berupa hak pendidikan sebagai makhluk sosial dan warga negara Indonesia serta mengembangkan potensi yang dimiliki berupa pengetahuan, keterampilan dan sikap semaksimal mungkin sesuai dengan batas kemampuan individu agar bermanfaat bagi dirinya, lingkungannya, dan masyarakat luas.

Tujuan pendidikan nonformal sebagai pendidikan di luar sekolah yang menghasilkan individu yang memiliki pengetahuan, keterampilan, dan sikap dalam mengembangkan diri dalam kehidupan sosial baik dilingkungannya sendiri maupun di luar lingkungannya memerlukan dukungan dalam pengelolaannya berupa proses manajemen yaitu berupa perencanaan, pengorganisasian, pelaksanaan meliputi pengarahan dan motivasi, serta pengawasan dalam setiap kegiatan yang diselenggarakan oleh pendidikan nonformal agar visi, misi, dan tujuan pendidikan nonformal dapat tercapai secara efektif dan efisien.

Pengelolaan penyelenggaraan kegiatan PKBM dilakukan melalui tahapan pengelolaan yang telah disampaikan oleh para ahli, yaitu tahap perencanaan, 
pengorganisasian, pelaksanaan, dan pengevaluasian (Stoner, 1986; Robbins, 2003). Perencanaan merupakan satu kegiatan yang dilakukan untuk mencapai tujuan yang telah ditetapkan berkenaan dengan suatu proses kegiatan yang dilakukan secara berkesinambungan dalam suatu organisasi melalui tahapan berdasarkan tujuan yang telah ditetapkan. Dalam pengelolaan PKBM hal yang perlu dilakukan pengelolaan berkenaan dengan kurikulum, warga belajar, tenaga pendidik dan kependidikan, saran dan prasarana, keuangan, hubungan dengan masyarakat, dan layanan khusus (Rahmat, 2017:49).

Sebagai upaya untuk mewujudkan peran penting pendidikan non-formal, para pengelola pendidikan nonformal dalam perencanaan pengelolaan satuannya melakukan beberapa strategi baik dalam program layanan, pendanaan, maupun membangun jejaring kemitraan dengan pihak atau organisasi lain. Berkenaan dengan pendanaan, penyelenggaraan pendidikan nonformal masih sangat tergantung pada alokasi anggaran pemerintah melalui mekanisme Anggaran Pendapatan dan Belanja Negara (APBN) dan Anggarana Belanja dan Pendapatan Daerah (APBD) (Rizka-Arief, \& Hardiansyah, 2017; Suryono \& Tohani, 2014). Selain perencanaan terkait pendanaan, peningkatan kegiatan belajar mengajar melalui beberapa metode dan media yang dapat meningkatkan pengetahuan, sikap dan keterampilan peserta didik juga merupakan perencaan yang ditetapkan oleh pendidikan nonformal (Nurlaela, 2020; Ekosiswoyo \& Sutarto, 2015; Mulyano, 2015).

Mengingat keterbatasan pendanaan dan keterbatasan kepemilikan sarana prasarana, satuan pendidikan nonformal maka faktor terpenting lainnya dalam penyelenggaraan pendidikan non-formal adalah jejaring kemitraan. Jejaring kemitraan diistilahkan dengan networking atau partnership. Jejaring kemitraan merupakan suatu hal yang yang penting dalam penyelenggaraan suatu kegiatan (Akhtar, Awan, Ismail, \& Naveed, 2017; Klerk \& Saayman, 2012; Alvarez, Marin, Fonfria, 2009; Mentzas, Apostolou, Young, 2001; Szarka, 1990).

Jejaring kemitraan merupakan kegiatan yang memuat beberapa unsur pokok yaitu adanya dua pihak atau lebih, adanya interaksi dan adanya tujuan bersama. Jejaring kemitraan memberikan arahan pada adanya keselarasan, keseimbangan dan interaksi yang dapat memenuhi kepentingan antar pihak yang bermitra. Jejaring kemitraan merupakan bentuk kolaborasi yang dilakukan oleh suatu organisasi sebagai upaya mencapai visi, misi, dan tujuan organisasi serta mempertahankan keberlangsungan suatu organisasi (Stachova, Popula, Stacho, \& Kabnove, 2019;Casey, 2008, Buys, \& Bursnall. 2007) 
Bush \& Bell (2005) menyatakan bahwa jejaring kemitraan adalah upaya untuk melakukan hubungan dengan melibatkan kelompok masyarakat, industry, dan kelompok usaha. Jejaring kemitraan adalah suatu keahlian yang harus dimiliki oleh pengelola suatu lembaga dan dapat dikembangkan melalui berbagai latihan (Klerk, 2010), dan merupakan pengetahuan dasar yang harus dipahami oleh para pengelola (Moensted, 2006). Jejaring kemitraan berpengaruh pula terhadap karir seorang pimpinan (Ishak, 2017) dan berpengaruh juga dalam meningkatkan kualitas (Champman, 2008).

Pendidikan nonformal merupakan penyedia layanan pendidikan bagi masyarakat dengan melibatkan berbagai pihak luar melalui jaringan kerjasama (Shresta, Wilson, \& Singh, 2008; Peel, Peel, \& Bakery;Trim, 2003; Dhillon, 2013). Kitchen (1997) mendeskripsikan bahwa jejaring kemitraan adalah hal yang sangat penting dalam penyelenggaraan organisasi agar organisasi dapat mencapai tujuan yang telah ditetapkan secara efektif dan efisien. Jejaring kemitraan adalah usaha yang dilakukan oleh individu atau sekelompok orang untuk mencapai tujuan bersama dalam pola dan bentuk yang beragam (Ruyadi, 2004). Sedangkan Rahmat (2017) menekankan bahwa kemitraan merupakan salah satu faktor penting yang harus dibangun untuk meningkatkan produktifitas, efektifitas, dan efisiensi pendidikan di satuan pendidikan nonformal.

Konsep jejaring kemitraan antar organisasi menurut Samboteng dan Kasmad (2014) adalah:

1. Memiliki satu tujuan bersama yang ingin dicapai;

2. Untuk mencapai tujuan diperlukan kerjasama;

3. Adanya ketidakpastian sumberdaya yang tidak dimiliki dan ketergantungan terhadap sumberdaya tersebut.

Sedangkan Hill (2002) menyebutkan bahwa jaringan kemitraan yang dibangun sesuai dengan visi dan misi lembaga. Bentuk jejaring kemitraan menurut Ilham (2020) dapat berupa koalisi, tawar menawar, bekerjasama, atas dasar kerukunan, dan koptasi yang bertujuan untuk memenuhi kebutuhan kedua belah pihak yang bekerjasama dan dibangun sesuai dengan tujuan organisasi tersebut.

Berdasarkan uraian diatas, maka jejaring kemitraan adalah suatu bentuk kerjasama yang dibangun oleh organisasi dalam upaya mencapai visi, misi, dan tujuan organisasi dengan menyadari secara penuh keterbatasan sumberdaya yang dimiliki dan tantangan perkembangan teknologi informasi agar mampu bersaing secara sehat dan mempertahankan keberadaan organisasi. Oleh karena itu tujuan penelitian ini adalah untuk 
mendeskripsikan jejaring kemitraan menurut para pengelola satuan pendidikan non-formal sebagai informasi bagi pemangku kebijakan pendidikan nonformal dan para stakeholder berkenaan dengan manfaat jejaring kemitraan bagi penyelenggaraan pendidikan nonformal.

\section{Metode Penelitian}

Penelitian ini menggunakan pendekatan deskriptif kualitatif karena bertujuan untuk mendeskripsikan pandangan para pengelola lembaga pendidikan non-formal dari beberapa wilayah kabupaten yang berada di Provinsi Jambi. Lembaga pendidikan nonformal yang dimaksud adalah Pusat kegiatan Belajar Masyarakat (PKBM) yang berlokasi di wilayah kabupaten Bungo, Merangin, dan Batanghari. Pemilihan informan pada penelitian ini telah ditetapkan terlebih dahulu oleh peneliti dengan pertimbangan biaya, waktu, dan energi

Pengumpulan data dalam penelitian ini dilakukan melalui observasi, wawancara, dan dokumen. Observasi dilakukan dengan mengajukan pertanyaan secara umum kepada informan berkenaan dengan jejaring kemitraan dalam pengelolaan pendidikan non-formal. Sedangkan wawancara dilakukan secara langsung dengan meminta persetujuan informan terlebih dahulu pada saat kegiatan workshop pengelola lembaga pendidikan non-formal yang diselenggarakan oleh BP PAUD DIKMAS Provinsi Jambi, pada tanggal 19-24 Oktober 2020. Jumlah informan dalam penelitian ini adalah 15 pengelola lembaga pendidikan non formal yang terdiri atas pengelola 15 pengelola PKBM yang tersebar di tiga wilayah Kabupaten di Provinsi Jambi, yaitu Kabupaten Batanghari, Merangin, dan Bungo. Data berupa dokumen yaitu jurnal dan buku teks, berita resmi berkenaan dengan pendidikan non formal dan dokumen lainnya.

Data yang telah terkumpul, dilakukan analisis dengan mengikuti metode analisis data kualitatif yaitu dengan tahapan mereduksi data, melakukan display data sesuai dengan tema yang telah ditetapkan oleh peneliti, dan menarik kesimpulan atau verifikasi. Adapun setiap informan dalam penelitian ini diberi kode dengan mengunakan huruf dan angka yang merujuk pada nomor informan, seperti P1. P1 merupakan informan yaitu pengelola satuan pendidikan non-formal PKBM yang pertama dan seterusnya. Data yang telah dianalisis selanjutnya dilakukan uji keabsahannya dengan melalui trianggulasi data, yaitu data yang bersumber dari teori, lapangan, dan sumber lainnya. 
Adapun pertanyaan utama dalam penelitian ini adalah "bagaimana pandangan pengelola lembaga PNF PKBM) berkenaan dengan jejaring kemitraan?" untuk menjawab pertanyaan utama, maka peneliti menetapkan rincian pertanyaan sebagai berikut:

1. Apa yang dimaksud dengan jejaring kemitraan dalam pendidikan nonformal menurut pengelola PKBM?

2. Bagaimana karakteristik jejaring kemitraan dalam pengelolaan pendidikan nonformal yang dipilih oleh para pengelola PKBM?

3. Apa saja faktor yang menjadi kendala dalam membangun jejaring kemitraan bagi PKBM?

\section{Hasil dan Pembahasan}

\section{Pemahaman Pengelola PKBM berkenaan jejaring kemitraan}

PKBM sebagai penyelenggara program layanan pendidikan nonformal memiliki peran dan fungsi yang penting untuk meningkatkan kemampuan kognitif, mengembangkan kualitas dan pengaktualisasian diri peserta didik serta peran dan fungsi lain yang penting untuk menghasilkan sumberdaya manusia berkualitas sebagai mana yang diutarakan Folley (2000) dan Rahmat (2017), maka satuan PKBM berupaya mewujudkan peran dan fungsinya tersebut melalui serangkaian kegiatan berdasarkan kurikulum dan pedoman penyelenggaraan satuan PKBM.

Terkait keterbatasan sumberdaya yang dimiliki PKBM dan ketergantungan pada pendanaan dalam menyelenggarakan program layanan yang tersedia, maka satuan PKBM memerlukan jejaring kemitraan agar program layanan dapat berjalan sebagaimana yang direncanakan dalam pengelolaan satuan PKBM. Hal ini sesuai dengan pernyataan yang disampaikan oleh pengelola satuan PKBM yaitu P1 dan P8 secara berurutan:

P1: “ bagi saya jaringan kemitraan itu sangat penting, karena satuan kami menyelnggarakan program layanan yang dananya tidak dipungut dari peserta didik, kami hanya memiliki sumberdana pemerintah saja"

P8: " bermitra adalah salah satu upaya agar satuan PKBM kami dapat berjalan sebagaimana mestinya, karena tanpa mitra kami tidak akan bisa menyelenggaraan program layanan karena keterbatasan dana dan fasilitas di lembaga kami”

Pernyataan yang disampaikan oleh P1 dan P8 senada dengan pernyataan dari pengelola 
satuan PKBM lainnya. Keterbatasan dana dan fasilitas merupakan salah satu hal yang memicu satuan PKBM untuk melakukan kerjasama dengan pihak atau organisasi lain. Sebagaimana yang diketahui bahwa penyelenggaraan program layanan satuan PKBM sangat tergantung pada APBN dan APBD (Rizka-Arief, \& Hardiansyah, 2017; Suryono $\&$ Tohani, 2014). Berdasarkan uraian diatas dapat disimpulkan bahwa pemahaman pengelola satuan PKBM berkenaan dengan jejaring kemitraan adalah serangkaian kegiatan yang dilakukan bersama-sama dengan pihak lain untuk terwujudnya penyelenggaraan program layanan pada satuan PKBM dikarenakan keterbatasan dana dan fasilitas yang dimiliki oleh satuan.

Pemahaman mengenai jejaring kemitraan yang dikemukakan oleh para pengelola satuan PKBM menunjukkan bahwa jejarig kemitraan yang dibangun masih terbatas pada pemikiran praktis berkenaan dengan terlaksananya program layanan yang disediakan.

\section{Karakteristik jejaring kemitraan menurut pengelola PKBM}

Pengelolaan PKBM sebagai penyelenggara pendidikan nonformal telah diatur secara jelas dalam undang-undang pendidikan nasional nomor 20 tahun 2003 yaitu sebagai pengganti, penambah dan pelengkap pendidikan formal dalam rangka mendukung pendidikan sepanjang hayat yang dapat didirikan oleh seseorang atau sekelompok orang. Tujuan penyelengaraan program layanan PKBM sebagaimana yang dinyatakan dalam undang-undang memerlukan jejaring kemitraan dalam bsesuai dengan kebutuhan masingmasing satuan PKBM.

Jejaring kemitraan PKBM dengan melibatkan kelompok masyarakat, industry, dan kelompok usaha, sehingga pengelola PKBM perlu keahlian dan pengetahuan mengenai framework jejaring kemitraan (Ishak, 2017;Bush \& Bell, 2005; Klerk, 2010; Moensted, 2006). Karakteristik jejaring kemitraan yang dibangun oleh satuan PKBM adalah sebagai bentuk upaya pencapaian tujuan penyelenggaraan satuan PKBM dengan sumberdaya yang terbatas. Hal ini sesuai dengan pernyataan yang dikemukakan oleh Hills (2014), Samboteng dan Kasmad (2014) bahwa karakteristik jejaring kemitraan yang dibangun diantaranya berupa upaya pencapaian tujuan karena ketidakpastian sumberdaya yang dimiliki agar visi, misi, dan tujuan PKBM tercapai (Stachova, Popula, Stacho, \& Kabnove, 2019; Casey, 2008, Buys, \& Bursnall. 2007).

Berdasarkan hasil data yang diperoleh pengelola satuan pendidikan nonformal, jejaring kemitraan yang dibangun memiliki karakteristik berupa pemodalan, 
peminjaman/penggunaan fasilitas, dan narasumber. Berikut uraian karakteristik jejaring kemitraan satuan pendidikan non-formal (PKBM):

1. Pemodalan

Kepemilikan modal dalam bentuk dana tunai merupakan hal yang sangat penting dalam peyelenggaraan kegiatan di satuan PKBM, sehingga satuan perlu membangun jejaring kemitraan dengan pihak yang dapat memberikan modal. Sebagaimana pernyataan yang disampaikan oleh informan P3:

"saat ini saya baru saja membuat kerjasama dengan pihak yang dapat memberikan peminjaman uang untuk memudahkan bagi saya dalam mengelola program layanan di satuan saya, saya bekerjasama dengan koperasi di wilayah saya..."

Sejalan dengan pernyataan yang dikemukakan oleh P3, P7, P12, dan P15 memberikan pernyataan yang sama berkenaan dengan bentuk jejaring kemitraan yang dijalin terutama dalam peminjaman uang. Hal ini, menurut para pengelola satuan pendidikan non-formal dikarenakan minimnya dana operasional yang dimiliki oleh satuan. Para pengelola menyatakan bahwa satuan tidak memungut dana pendidikan dari peserta didik. Satuan pendidikan hanya memperoleh dana batuan dari pemerintah dalam menyelenggarakan program layanan di satuannya. Selain membangun jejaring kemitraan dengan koperasi simpan pinjam, satuan juga menjalin kerjasama dengan perbankan seperti bank perkreditan rakyat.

2. Peminjaman/penggunaan fasilitas

Fasilitas kegiatan pembelajaran yang dimiliki satuan PKBM masih belum mencukupi untuk beberapa kegiatan yang dilakukan pada setiap program layanan. Oleh karena itu satuan melakukan kerjasama dengan sekolah dan kantor desa setempat untuk penggunaan fasilitas belajar baik untuk program kesetaraan maupun kecakapan hidup.

P1 menyatakan bahwa program layanan yang diselenggarakan oleh satuan mereka belum memiliki fasilitas memadai, sehingga dalam pelaksanaan kegiatan mereka menggunakan gedung sekolah yang berada disekitar lokasi PKBM, dan P5 menyatakan selain dengan sekolah, satuan melakukan kerjasama dalam bentuk menggunakan kantor desa sebagai tempat kegiatan belajar. Beberapa informan lain juga menyatakan hal yang sama.

Selain itu, dari hasil data dilapangan ditemukan bahwa rata-rata pengelola satuan pendidikan melakukan kerjasama dengan sekolah selain peminjaman ruang belajar 
juga berkenaan dengan tempat pelaksanaan kegiatan ujian nasional, seperti salah satu pernyataan yang informan P4 yang senada dengan pernyataan yang disampaikan oleh informan lainnya:

“ karena lembaga kami masih belum cukup memiliki ruang belajar, kami meminjam gedung sekolah yang dekat dengan lokasi kami, sebagai tempat belajar...selain itu kami juga bekerjasama dengan sekolah tertentu untuk tempat menyelenggarakan ujian akhir nasional"

Selanjutnya P2, P5, P7, P8, P10, dan P13 mengemukakan hal yang sama bahwa kemitraan yang mereka dengan sekolah tertentu adalah berkenaan dengan tempat ujian akhir saja, karena mereka telah memiliki ruang belajar sendiri, bahkan untuk kegiatan yang sifatnya keterampilan seperti menjahit, bengkel,dan lainnya mereka melakukan kerjasama dengan pusat keterampilan yang mereka butuhkan.

3. Narasumber

Bentuk jejaring kemitraan lain yang dijalin leh para pengelola satuan PKBM adalah dalam bentuk penyediaan narasumber yang dapat meningkatkan pengetahuan dan keterampilan yang dibutuhkan oleh peserta didik pada satuan PKBM. Hasil data menunjukkan hampir seluruh satuan PKBM menjalin kemitraan dengan pihak lain yang berkontribusi dalam peningkatan pengetahuan dan keterampilan sebagaimana yang diutarakan oleh salah satu informan yaitu, P8:

“ kami sering meminta salah satu pengajar dari pihak luar yang memiliki pengetahuan dan keterampilan yang kami butuhkan bagi peserta didik, misalnya dari lembaga kursus ataupun individu dari komunitas tertentu yang dapat meningkatkan pengetahuan dan keterampilan yang dibutuhkan oleh peserta didik kami”.

Dari hasil data yang diperoleh berkenaan dengan karakteristik jejaring kemitraan yang dibangun oleh para pengelola satuan PKBM memiliki pola yang sama antar pengelola adalah pencapaian tujuan penyelenggaraan program layanan yang tersedia dengan keterbatasan sumberdaya yang dimiliki baik sumberdaya materi maupun non materi.

Oleh karena itu, satuan PKBM membangun jejaring kemitraan dalam bentuk pemodalan yaitu membuat pernyataan perjanjian kerjasama dengan pihak yang dapat memberikan bantuan dalam pendanaan seperti koperasi simpan pinjam dan perbankan. Sementara jejaring kemitraan dalam bentuk peminjaman /fasilitas dan narasumber, sebagian besar pengelola satuan PKBM hanya atas dasar saling percaya dan saling kenal 
(relatiniship). Sehingga sebagian besar pengelola satuan PKBM tidak membuat pernyataan perjanjian kerjasama sebagaimana dalam bentuk pemodalan.

\section{Faktor-faktor yang menjadi kendala dalam membangun jejaring kemitraan}

Membangun jejaring kemitraan bagi organisasi baik yang bergerak di sektor pendidikan maupun tidak, memiliki kendala sesuai dengan kondisi organisasi tersebut. Berdasarkan hasil data yang diperoleh, kendala satuan dalam mebangun jejaring kemitraan bersumber dari dalam satuan sendiri yaitu terletak pada pemikiran praktis para pengelola hanya terbatas pada pemikiran agar program layanan yang tersedia dapat terlaksana

Hal ini terlihat dari beberapa pernyataan yang disampaikan oleh hampir semua informan, ketika peneliti menanyakan permasalahan berkenaan dengan pertanyaan penelitian ini, para informan menyatakan bahwa mereka baru menyadari bahwa banyak celah dan kesempatan yang bisa mereka gunakan untuk membangun jejaring kemitraan. Salah satu pernyataan disampaikan oleh P7 selaras dengan pernyataan yang dismapaikan oleh informan lainnya, sebagai berikut:

" saya hanya membuat kerjasama dengan koperasi saja, saya tidak memikirkan untuk membangun kemitraan dengan pihak lain, karena menurut saya yang paling penting adalah bagaimana program layanan di satuan saya bisa berjalan degan keterbatasan dana yang satuan kami miliki”. P8 menyatakan bahwa dalam membangun jejaring kemitraan dengan organisasi lain pada dasarnya berkenaan dengan modal dan peminjaman fasilitas pembelajaran seperti ruang kelas dan tempat mengadakan ujian nasional. Lebih lanjut P8 menyatakan bahwa jejaring kemitraan yang dibangun didasarkan pada kesepakatan saja tanpa membuat surat perjanjian kerjasama. Pernyataan P8 selaras dengan pernyataan yang disampaikan oleh pengelola PKBM yang menjadi informan dalam penelitian ini yaitu P11 dan P15 yang menyatakan bahwa untuk membangun jejaring kemitraan mereka lebih memfokuskan pada pihak yang dapat memberika bantuan pendanaan seperti koperasi, perbankan, dan dinas tertentu.

Berdasarkan uraian diatas, maka terlihat faktor yang mempengaruhi para pengelola satuan PKBM dalam membangun jejaring kemitraan adalah keterbatasan pengetahuan yang dimiliki oleh pengelola, yang lebih mengedepankan pada pemikiran praktis berkenaan dengan tetap berjalannya program layanan yang tersedia pada satuannya, dan belum memikirkan membangun jejaring kemitraan dengan pihak lain yang dapat mendukung program layanan meskipun tidak dalam bentuk materi (uang). 


\section{Kesimpulan}

Berdasarkan hasil dan pembahasan maka dapat disimpulkan bahwa membangun jejaring kemitraan dalam pandangan pengelola satuan PKBM masih bersifat praktis yaitu terlaksananya program layanan yang tersedia meskipun dengan keterbatasan pendanaan dan fasilitas yang dimilki oleh satuan PKBM dengan uraian sebagai berikut; 1)berkenaan dengan pemahaman jejaring kemitraan para pengelola menyadari pentingnya membangun jejaring kemitraan dengan pihak/organisasi lain agar program layanan yang tersedia dapat terlaksana dengan baik, 2)karakteristik kerjasama satuan PKBM yaitu upaya pencapaain tujuan dengan keterbatasan sumberdaya dalam bentuk pemodalan, peminjaman/penggunaan fasilitas dan narasumber untuk membekali peserta didik dengan pengetahuan dan keterampilan, dan 3)faktor yang menjadi kendala dalam membangun jejaring kemitraan pada satuan PKBM adalah pemikiran praktis terbatas pada terselenggaranya program layanan yang tersedia sesuai dengan perencanaan yang dibuat.

\section{Daftar Pustaka}

Arefianto, L. 2020. Role of community learning center (CLC) "Handayani" batik training program in eradicate extreme poverty. Empowerment: Jurnal ilmiah studi pendidikan luar sekolah, Vol 9 (1)

Ekosiswoyo, R., \& Sutarto, J. 2015. Model pembelajaran pendidikan kesetaraan berbasis keterampilan vokasional. Journal of non-formal education: Vol 1(1)

Folley, G. 2000. Understanding adult education and training. Australia: Allen \& Unwin Hill, C. 2002. Network literature review:conceptualizing and evaluating networks. Di akses melalui http://wwwsaychn.media/pdf/literaturereview pada hari Sabtu tanggal 12 Desember 2020

Ilham, M. 2020. Pengertian kerjasama, manfaat, bentuk, dan contoh kerjasama. Di akses dari materi belajar.co.id pada hari Rabu tanggal 23 Desember 2020

Joesoef, S. 1992. Konsep dasar pendidikan nonformal. Jakarta: Bumi Aksara

Kedrayate, A. (2012). Education for nation-building: the contribution of non-formal in Fiji. Adult education and development: Vol 58

Kitchen, P. 1997. Public relations, principles, and practice. London: International Thomson Business Press

Marzuki, S. 2009. Dimensi-dimensi pendidikan nonformal. Malang: UNM Press 
Mulyono-Eko, S. 2015. Model pemberdayaan masyarakat untuk peningkatan literasi berdasarkan kewirausahaan mandiri melalui PKBM di Kota Semarang. Journal of non-formal education: Vol 1(1)

Nurlaela. 2020. Enhancing learners' reading competency through the project-based precooperative literacy ( descriptive study at CLC Hikmah district Ciamis, CLC Al ghifari district Cirebon, and CLC Geger sunten district West Bandung. Empowerment: Jurnal ilmiah studi pendidikan luar sekolah: Vol 9 (2)

Peraturan Pemerintah No. 81 Tahun 2013 Tentang Pendirian Satuan Pendidikan Non Formal.

Rahayu, R. 2020. The role of TBM Sukamulya Cerdas managers in increasing literacy in the community environment through the literacy campaign program. Empowerment: Jurnal ilmiah studi pendidikan luar sekolah: Vol 9 (2)

Rahma-Arina, Z., \& Zulkarnain, Z., \& Desyanti-Sugeng, E., \& Wahyuni, S. 2019. The role of community learning center $(C L C)$ in providing nonformal education service based on entrepreneurship. Journal of non-formal education: Vol. 5 (2)

Rahmat, A. 2017. Manajemen Pendidikan Nonformal. Ponorogo: Wade.

Rizka-Arief, M., Hardiyansyah, R. 2017. Analisis strategi fund raising dalam penyelenggaraan program pendidikan non formal pada pusat kegiatan belajar masyarakat Ceria. Journal of non-formal education: Vol. 3 (1)

Robbins, S.P. 2003. Organizational Behavior. Indeks (Terj). Jakarta: PT indeks Kelompok Gramedia.

Ruyadi, Y. 2004. Arti penting kerjasama dalam keberagaman masyarakat. Jakarta: Direktorat pendidikan menengah kejuruan Dirjen pendidikan dan menengah Departemen Pendidikan nasional.

Stoner, J.A.F. 1986. Management ( $3^{\text {rd }}$ ed). London: Prentice-Hall.

Suryono., \& Tohani. 2014. Evaluasi pendidikan nonformal berbasis pendidikan kecakapan hidup dalam mengatasi kemiskinan di desa. Yogyakarta: Graha Cendekia.

Suryono, Y., \& Tohani, E. 2016. Inovasi pendidikan non-formal. Yogyakarta: Graha media.

Undang-Undang No. 20 tahun 2003 Tentang Sistem pendidikan Nasional. 